\title{
Applying Language Learning Strategies in the Foreign Language Listening Comprehension: A Study of Islamic Senior High School Students
}

\author{
Dian Pertiwi \\ State Islamic University of Raden Fatah, Palembang, South Sumatra \\ dianpertiwi6869@gmail.com
}

\begin{abstract}
The main purpose of the present study was to empirically investigate the possible correlation and the influence between students' language learning strategies and listening comprehension. The population of this study was 138 eleventh grade students of Islamic Senior High School number 2 Palembang. The sample was all of eleventh grade students in social class. The total number of the student was 138. Since 16 students were absent, so the sample consisted of 122 students. To collect the data in order to measure the students' language learning strategies and listening comprehension, SILL (strategy inventory in learning language) and listening comprehension test from TOEFL Junior test were used in this study. The Pearson correlation was used in analyzing the data using SPSS 16. The result from questionnaire showed that most of the students used metacognitive strategies were in medium level and sometimes used language learning strategies. The result from listening comprehension test showed that most of the students were in very poor level. Furthermore, there was no significant correlation between the two variables that can be seen from the correlation coefficient or $r$-obtained (-.011) was lower than $r$-table $(0.1779)$ then the level of probability or sig. value (.902) was higher than .05 . From the result, it can be concluded that there was no significant correlation between language learning strategies and listening comprehension of eleventh grade students of Islamic Senior High School number 2 Palembang.
\end{abstract}

Keywords: language learning strategies, listening comprehension

\section{Introduction}

In this globalization era, everybody must have good communication ability to support their activity in daily life. It is in line with what Dewi (2015), Haryanto and Mukminin (2012), Mukminin, Ali, and Fadloan (2015), and Jackson and Stockwell (1996) stated that English was used in every corner of the world as a medium to interact among people from different cultural, ethnic, and social backgrounds (Abrar, Mukminin, Habibi, Asyrafi, Makmur, \& Marzulina, 2018; Makmur, Mukminin, Ismiyanti, \& Verawati, 2016; Mukminin, Masbirorotni, Noprival, Sutarno, Arif, \& Maimunah, 2015; Mukminin, Muazza, Hustarna, \& Sari, 2015). In addition, Bozorgian (2012) states "listening skill occupies almost 50\% of daily communications" (p. 2). It means that listening skill has very high degree of influence and it is certain that listening occupied the 
main aspects of the effective communication for human in daily life. Listening is also very important for students in acquisition foreign language. According to Hamouda (2013), "no one can deny the importance of listening skills in foreign language learning because the key to acquire a language is to receive language input" (p. 113). It is supported by De Chazal (2014) who states that students need good listening comprehension skill to interpret what people are saying in various academic situations.

However, listening has not drawn much attention from both teachers and learners, they are generally less aware of its importance. Hamouda (2013) claims "in classrooms, teachers seem to test, not to teach listening and students seem to learn listening, not listening comprehension" (p. 115). Students usually listen to a text, respond to questions, and check their answers. Furthermore, students in Indonesia have unsatisfactory level in listening skill. It can be seen from a survey that has been conducted by EF Standard English Test (2015). Indonesian students are on average at B1 level (independent user) in English listening skill among 16 countries. From the fact, it shows that Indonesian students are not proficient yet in listening. Goh (2000) proposed ten common listening comprehension problems as follows; "1) quickly forget what is heard; 2) do not recognize words they know; 3) understand words but not intended the message; 4) neglect the next part when thinking about meaning; 5) unable to form a mental representation from words heard; 6) cannot chunk streams of speech; 7) miss the beginning of the texts; 8) concentrate too hard or unable to concentrate; 9) do not understand subsequent parts of input because of earlier problems; and 10) is confused about the key ideas in the message" (p. 59-60). Meanwhile, Malkawi (2010) mentions three problems of listening that senior high school students usually face, such as "1) speech speed; 2) limited knowledge of vocabulary and structure of sentences; and 3) limited knowledge of topic in question" (p. 773). Goh (2000) add, "It was because the students were not aware about the strategies and sometimes forgot to apply them while they were engaged in listening" (p. 143). He also explained that most of students did not know much about listening strategies.

In learning language, learning strategies have become crucial part to help the students successful in acquiring the language (Abrar \& Mukminin, 2016; Haryanto \& Mukminin, 2012; Mukminin, Muazza, Hustarna, \& Sari, 2015; Mukminin, Ali, \& Fadloan, 2015). Pannak and Chiramanee (2011) states "one of the important factors contributing to successful language learning is language learning strategies" (p. 3). Becoming one of the factors that determine language learner success in acquiring language makes learning strategy very important for teachers and learners (Erlina, Marzulina, Pitaloka, Astrid, Fikri Yansyah, \& Mukminin, 2018; Habibi, Sofwan, \& Mukminin, 2016).). Theory about language learning strategies comes from Oxford (1990) as she emphasizes "the best language students have used strategy" (p. 1). Oxford (1990) divided language learning strategies into two major classes; direct and indirect. Direct strategy consists of three groups (memory, cognitive and compensation) and indirect consists of three groups (metacognitive, affective, and social). "Learning strategy makes learning easier, faster, more enjoyable, more self-directed, more effective, and more transferable to new situation" (Oxford, 1990, p. 8; Oxford, 2003, p. 274). It was also supported by many studies that the use of language learning strategy influenced the students' proficiency in foreign language especially in English proficiency. One example is the study conducted by Ou-Chun (2011) who found that language learning strategies of EFL students had significance correlation with their English proficiency. It means that by using language learning strategies, it can help the students achieve their goal in acquisition English foreign language well.

Language learning strategies is also an important part for senior high school students in learning language process in the classroom. To get their successful in acquisition foreign language, the students need to apply strategy in learning language. Lee (2010) states that learners use learning strategies in order to learn something more successfully. By applying 
learning strategy, it can make the students easy to understand the material quickly and make them more efficient in learning foreign language. It is also supported by Suwanarak (2012) who declared that the use of language learning strategies is linked with an achievement in the second language classroom and helps students become independent learners.

In association with students' listening comprehension in English, language learning strategies have big influences on students listening comprehension performance. It is proven by Moghadam, Ghanizadeh, and Pazhouhesh (2016) who declared that students' strategies in listening has a positive effect on their listening comprehension. "Successful listening can also be looked at in terms of the strategies the listener uses when listening" (Richard, 2008, p 11). From the evidence above, it can be concluded that language learning strategies influence students listening comprehension. It is important for teacher and students to know about it.

Based on the informal interview with the teacher and the eleventh grade students of MAN 2 Palembang, many students said that listening was difficult for them because they did not know what the speaker were saying, the speed of the speaker was too fast, and they were also lack of vocabulary. Most of the students did not know about language learning strategies. Meanwhile, the teacher said she just knew what language learning strategies were but she did not know specifically about language learning strategies. She also added that she taught listening without knowing the students language learning strategies. Because of those reasons, the researcher wants to examine the correlation between language learning strategies and listening comprehension. The objectives of the study were: (1) to find out if there is significant correlation between language learning strategies and student's listening comprehension of eleventh grade students of MAN 2 Palembang (2) to know if the language learning strategies influence students' listening comprehension of eleventh grade students of MAN 2 Palembang.

\section{Literature Review}

\section{Concept of language learning strategy}

There are so many theories about language learning strategies from scholars. Chamot and Kupper (1989) declare, "learning strategies are technique which students use to comprehend, store, and remember new information and skills" (p. 15-17). They classified into three types; metacognitive, cognitive or social and affective. Oxford (1990) emphasizes "the best language students have used strategy" (p. 1). Oxford (1990) divided language learning strategies into two major classes; direct and indirect. Direct strategy consists of three groups (memory, cognitive and compensation) and indirect consists of three groups (metacognitive, affective, and social). Learning strategy makes learning easier, faster, more enjoyable, more self-directed, more effective, and more transferable to new situation (Oxford, 1990, p. 8; Oxford, 2003, p. 274). Chamot (2005) also explained his new theory about language learning strategies. He defines learning strategies as procedures that facilitate a learning task. Strategies are most often conscious and goal-driven, especially in the beginning stages of tackling an unfamiliar language task. Hurd and Lewis (2008) states "more proficient learners also orchestrate strategy use more effectively, combining strategies into strategy clusters for complex tasks and making sure that any chosen strategy is appropriate at the time " (p. 51). Less proficient L2 learners often use strategies in a desperate way, not knowing how to identify the needed strategies.

From the theory above, it indicated that good language learners always use language learning strategy in the acquisition process of the foreign language. By understanding the language learning strategies and knowing how to choose the appropriate strategy needed by the students, will direct the students to get their target language. In other words, language learning strategy is one of the factors that determine students' success in learning a language. 


\section{Classification of language learning strategies}

Oxford (1990) divided two major classes of learning strategy; direct and indirect. "The direct class is composed of three groups (memory, cognitive and compensation)" (Oxford, 1990 , p.14). Memory strategies are for remembering and retrieving new information, for examples; remember acronyms, grouping the word (e.g., all noun or verbs), and image. Next is cognitive strategies for understanding and producing the language. Second, cognitive strategies enable learners to manipulate the language material in direct ways, e.g., through reasoning, analysis, note-taking, summarizing, and translating. The last is compensation strategies for using the language despite knowledge gaps, such as guessing wisely, using linguistics clue, using gestures, switching to the native language, and using a synonym or description.

The second major class-indirect strategies, "This class is made up of metacognitive strategies, affective strategies, and social strategies" (Oxford, 1990, p. 15). First is metacognitive strategies for coordinating the learning process, such as planning, setting goals and objectives, monitoring errors, and evaluating progress. Then, affective strategies for regulating emotions, such as strategies including encouraging oneself through positive self-talk, rewarding yourself, talking with someone about your feelings learning the target language and so on. The last is social strategies for learning with others, such as asking questions, asking for clarification, asking for help, and talking with a native-speaking conversation partner.

\section{Concept of listening comprehension}

Listening is the ability to identify and understand what others are saying in various situation. Moghadam, Ghanizadeh, and Pazhouhesh (2016) states "people have to comprehend what their interlocutors say and respond to it. If they are able to listen effectively, then they will have a meaningful communication" (p. 11). To have good listening skills, students must be able to comprehend all of the aspects when listening. Golchi (2012) states "listening includes comprehension of meaning-bearing, words, phrases, clauses, sentences and connected discourse" (p. 115). The word comprehension is reflection of the knowledge and skills that students have to acquire in listening. That is the reason why listening comprehension is a complex process.

There have been a large number of scholars that present about listening comprehension towards the concept. Liubiniene (2009) defines "listening comprehension is more than extracting meaning from incoming speech" (p. 89). It is a process of matching speech with the background knowledge, i.e. what the listeners have already know about the subject. Bđlokcuoğlu (2014) asserts "listening comprehension is strongly believed to be a process of interaction between the listeners' background knowledge and the expected knowledge in the spoken text, that is, listeners employ all relevant previously stored knowledge to comprehend the incoming input" (p.83). Meanwhile, Yousefinia (2012) states "listening comprehension means the process of understanding speech in a second or foreign language" (p. 4). It is the perception of information and stimuli received through the ears. It can be concluded that listening comprehension is the process of understanding of aural message from the speaker and match it to the listener knowledge.

\section{Importance of listening comprehension}

Many researchers believe that listening comprehension is crucial aspect in language acquisition since the last two decades. Moghadam et.al (2016) declared "in communicative approaches to language teaching, listening has been emphasized in all levels of language learning" (p. 11). Jones (2003) claims, "listening comprehension activities provide students with the aural component of the target language to help them better hear the intricate sounds, enunciations, and content and develop their abilities to communicate with others in a target language" (p. 41). In relation to English language, the students need good listening 
comprehension ability to help them in the acquisition of the English language. Gilakjani and Ahmadi (2011) believe "an emphasis on listening comprehension as well as the application of listening strategies will help students to decode English input and to achieve greater success in English learning” (p. 986).

\section{Methodology}

\section{Research design}

In this study, I used a correlation research design. According to Fraenkel, Wallen, and Hyun (2012), "the correlation study mainly focuses on the possibility of relationships between only two or more variables investigated without any attempts to influence them" (p. 331). In this study, I used correlation research design to find out the correlation between two variables, explain, and inteprete the result that may appear. The procedures in this research are, first; I identified the students' learning strategy by using questionnaire. Second, by using TOEFL junior listening test, I found out the students listening comprehension score. Third, I found the correlation between two variables through SPSS based on the results of the questionnaire and listening test, and the influence of the variable(s). Last, explanation and interpretation of the results were discussed.

\section{Research site, sampling, and participants}

Fraenkel, Wallen, and Hyun (2012) defines population as the group of interest to the researcher, the group to whom the researcher would like to generalize the result of the study. In addition, Fraenkel and Wallen (1990) stated that population is the group of interest to the researcher, the group to whom the researcher would like to generalize the results of the study. ( as cited in ( as cited in Saputra \& Marzulina, 2015, p.5). Cresswell (2012) states "population is a group of individuals who have the same characteristic" (p. 142). The population of this study was all of the eleventh grade students of Islamic Senior High School number 2 Palembang in academic year of 2016/2017. The population consisted of 6 classes. According to Cresswell (2012), "sample is a subgroup of the target population that the researcher plans to study for generalizing about the target population" (p. 142). He also said that the sample can be selected from individuals who are representative of the entire population.

In this reserach, I used convenience sampling technique. The sample of this research were XI IIS 1, XI IIS 2, XI IIS 3, and XI IIS 4 classes. There were 138 students as sample. The researcher chose them as samples because they had equal background knowledge. In social class, many students did not know about language learning strategies and their learning strategy. They also had difficulties in learning listening.

\section{Data collection}

Questionnaire and listening test were used as the instruments which had been valid and reliable. SILL (strategy inventory in learning language) from Oxford (1990) version 7.0 was used to know students language learning strategies. According to Oxford and Burry-Stock (1995), "40-50 major studies, including a dozen dissertations and theses, have been done using the SILL involved 8000-8500 language learners" (p. 4). They also explained that the SILL appears to be the only language learning strategy instrument that has been extensively checked for reliability and validated in multiple ways. Fazeli (2011) found that the reliability score of SILL is 0.89. SILL questionnaire consisted 50 items and used likert scale 1-5. To avoid misunderstanding SILL questionnaire had been translated into Indonesian. The time to answer the questionnaire was 25 minutes. Listening comprehension test from TOEFL Junior standard test was used for testing students listening comprehension. TOEFL Junior 
standard test had been used in more than 50 countries including Indonesia and the reliability coefficients of the listening comprehension test was .87. The listening test consisted of 42 multiple choices questions. The time to answer the questions was 40 minutes.

\section{Data analysis}

For analyzing the data in this research, there were four steps. First, after distributing the SILL questionnaire to the students, the student's answers were calculated by using formula from Oxford (1990). The student's total answer in each part of SILL was divided with the total statement in each part. The highest average score from all part of SILL indicated which strategy that the students tended to use most frequently. After that, all the sums from students answer in different parts of SILL were divided by fifty $(\div 50)$. The result average score described students' frequency in using language learning strategies (LLS). The highest frequency level is 5.0 and the lowest is 1.0. Second, the students' listening comprehension answers was calculated by using a scoring system from MAN 2 Palembang. Third, in order to find out the correlation between language learning strategies (LLS) and Listening Comprehension of the eleventh grade students of MAN 2 Palembang, Pearson Product Moment correlation Coefficient in SPSS 16 was used. The last, in order to know the contribution of language learning strategies to listening comprehension of the eleventh grade students of MAN 2 Palembang, regression analysis was applied in this study.

\section{Findings and Discussion}

\section{Students' language learning strategies and listening comprehension}

Since 16 students were absent, so the sample consisted of 122 students. The descriptive statistical analysis of LLS for the participants was described as follows. The maximum score was 4.3, and the lowest score was 1.7. The mean of the language learning strategies scores for the participants was 2.9 and the standard deviation was .50. Equally important, the questionnaire results showed the most dominant strategy that students used was metacognitive strategy (37.4\%). In this research I also found that many students had more than one language learning strategies. The distributions of students' language learning strategies can be seen in the table below:

Table 1. Distributions of language learning strategies

\begin{tabular}{lcc}
\hline \multicolumn{1}{c}{ Category } & Frequency & Percentages \\
\hline Memory strategy & 10 & $7,2 \%$ \\
Cognitive strategy & 8 & $5,8 \%$ \\
Compensation strategy & 19 & $13,7 \%$ \\
Metacognitive strategy & 52 & $37,4 \%$ \\
Affective strategy & 14 & $10 \%$ \\
Social strategy & 36 & $25,9 \%$ \\
Total & 139 & $100 \%$ \\
\hline
\end{tabular}

The descriptive statistics analysis of listening comprehension for the participants was described as follows. The maximum score was 59.5, and the lowest score was 7.1. The mean of the listening comprehension score for the participants was 31.7 and the standard deviation is 9.32. Then, the listening comprehension results showed that most of the students were in very poor category. 113 students in were very poor category (93.6\%), 7 students were in poor category $(5.7 \%)$, and 2 students were in average category $(1.7 \%)$. 
Table 2. Distributions of listening comprehension

\begin{tabular}{clll}
\hline $\begin{array}{c}\text { Number of } \\
\text { Student }\end{array}$ & Interval & Category & Percentages \\
\hline 0 & $86-100$ & Very good & $0 \%$ \\
0 & $71-85$ & Good & $0 \%$ \\
2 & $56-70$ & Average & $1,7 \%$ \\
7 & $46-55$ & Poor & $5,7 \%$ \\
113 & $0-45$ & Very poor & $93,6 \%$ \\
\hline
\end{tabular}

\section{The results of normality test and linearity test}

The data interpreted normal if $\mathrm{p}>0,05$. If $\mathrm{p}<0,05$. It means the data are not normal. Kolmogorov-smirnov was used to see the normality. The results of normality indicated that the data from each variable were all normal and appropriate for data analysis with coefficients .646 for language learning strategies and .562 for listening comprehension. For linearity test, deviation of linearity was obtained. If probability is more than .05 , the two variables are liniear. The results showed that, the deviation from linerity between language learning strategies and listening comprehension was .348 and since it was higher than 0.05 , it was considered linear.

\section{Correlation between students' language learning strategies and listening comprehension}

Having analyzed the results of the questionnaire and students' listening comprehension test, it was found that the students' language learning strategies were not significantly correlated to their listening comprehension. The correlation coefficient or $r$ - obtain (-.011) was lower than $r$-table (0.1779) then the level of probability or (p) (.902) was higher than .05. It means that ho is rejected and h1 is rejected. Since there was no significant correlation between two variables, it is not necessary to do regression analysis because language learning strategies did not influence students' listening comprehension. Furthermore, the correlation analysis result showed as described in the following table.

Table 3. Correlation between language learning strategies and listening comprehension

\begin{tabular}{llll}
\hline & & $\begin{array}{l}\text { language } \\
\text { learning } \\
\text { strategies }\end{array}$ & $\begin{array}{l}\text { listening } \\
\text { comprehension }\end{array}$ \\
\hline $\begin{array}{l}\text { language learning } \\
\text { strategies }\end{array}$ & Pearson Correlation & 1 & -.011 \\
& Sig. (2-tailed) & & .902 \\
& $\mathrm{~N}$ & 122 & 122 \\
listening & Pearson Correlation & -.011 & 1 \\
comprehension & Sig. (2-tailed) & .902 & \\
& $\mathrm{~N}$ & 122 & 122 \\
\hline
\end{tabular}

The insignificant correlation result probably occurred because some factors in each side of the variables. From the language learning strategies side, the result showed that many students had more than one learning strategy. It made them unable to use the strategy appropriately because they were not aware about the strategy and how to use it. Hismanoglu (2000) strongly stressed that using the same good language learning strategies does not guarantee that bad learners will also become successful in language learning since other factors 
may also play role in success. Meanwhile, Oxford $(1990,12)$ states that strategies assessment and training might be necessary to help learners become more aware of the strategies they are using and evaluate the utility of those strategies.

Additionally, the result showed that language learning strategies (LLS) was not the only and the most dominant factor that affecting listening comprehension. The researcher assumed that there were some other factors affecting students listening comprehension. Based on the result of the informal observation when conducting the research, it could be seen that motivation was the most dominant since most of the students had low motivation during the test. Moreover, Bingol, Celik, Yildiz , and Mart (2014) states that "students' motivation is one of the crucial factors that affects listening comprehension " (p. 4). Another factor is experience in learning listening. Less experience in learning listening makes the students low in listening comprehension. Naning and Hayati (2011) explains "the different knowledge backgrounds of the students cause them to have different listening achievement too (p. 9). Also, students' vocabulary caused them to have different listening comprehension achievement. Other factors that should not be neglected are the teacher' methodology in teaching listening, the equipment, and the students' condition when joining the test. According to Ardila (2013), there are seven factors that affecting EFL learners' listening skills, namely, learner's motivation, paralinguistic features, vocabulary, concentration, teachers' methodology, the use of material and the learner's background. Norflee (2014) claims that there are also some factors such as listener' factor, background knowledge, speaking style and visual input.

In conclusion, this study failed in investigating the correlation and influence between language learning strategies (LLS) and listening comprehension of eleventh grade students of Islamic Senior High School number 2 Palembang. However, almost all of eleventh grade students of Islamic Senior High School number 2 Palembang used learning strategy occasionally and metacognitive strategy was the most dominant strategy that they used in learning language. Furthermore, language learning strategies (LLS) is also applicable for four skills (listening, speaking, reading, and writing), it means that there is possibility that language learning strategies correlate with others language skill.

\section{Conclusions}

Based on the findings of the study, three conclusions are drawn. First, the results of the questionnaire showed that metacognitive strategy was the dominant language learning strategy that students used. The students were also in medium level and sometimes they used language learning strategies. Meanwhile, the results of the listening comprehension test showed that most of the students were in very poor level. Second, the students' language learning strategies had no significant correlation to students' listening comprehension. The finding showed that $r$-obtained (-.011) was lower than $r$-table (0.1779) then the level of probability $(p)$ significance (sig.2-tailed) was .902 was higher than .05. It means there was no significant correlation between the students' language learning strategies and listening comprehension of the eleventh grade students of Islamic Senior High School number 2 Palembang. Since there was no significant correlation between two variables, it is not necessary to do regression analysis.

Some other factors may influence the result of this study, specfically; (1) many students used more than one learning strategies, were not aware about their strategy, and were confused on how to use it. As well, in answering the listening test, the students' had low motivation, lack of experience in learning listening, lack of vocabulary, and unprepared condition when joining the test. Besides, the teacher's method in teaching listening and the 
equipment that researcher used during listening test may also influence the result of this study.

\section{References}

Abrar, M., Mukminin, A., Habibi, A., Asyrafi, F., Makmur, M., \& Marzulina, L. (2018). "If our English isn't a language, what is it?" Indonesian EFL Student Teachers' Challenges Speaking English. The Qualitative Report,23(1), 129-145. Retrieved from https://nsuworks.nova.edu/tqr/vol23/iss1/9.

Abrar, M., \& Mukminin, A. (2016). International graduate classroom discussion engagement, challenges, and solving-strategies: Stories from Indonesian students in a United Kingdom university. Asia-Pacific Collaborative education Journal, 12(1), 5-20.

Ardila, M. A. C. (2013). Exploring factors affecting listening skills and their implications for the development of the communicative competence: A case study. Open. Writ. Doors. J, 10(2).

Bđlokcuoğlu, H. (2014). A schematic approach to teaching listening comprehension. EUL Journal of Social Sciences (V:I) LAÜ Sosyal Bilimler Dergisi.

Bingol, M. A., Celik, B., Yildiz, N., \& Mart, C. T. (2014). Listening comprehension difficulties encountered by students in second language learning class. International Journal on New Trends in Education and Their Implications, 4(4).

Bozorgian, H. (2012) Listening skill requires a further look into second/foreign language learning. ISRN Education, 2012 (2012). Retrivied from https://www.hindawi.com/journals/isrn/2012/810129/.

Chamot, A. U. (2005). Language learning strategy instruction: Current issues and research. Annual Review of Applied Linguistics, (25), 112-130.

Chamot, A. U., \& Kupper, L. (1989). Learning strategies in foreign language learning instruction. Interstate Research Associates, $V A$.

Creswell, J, W. (2012). Educationa research: Planning, conducting, and evaluating quantitative and qualitative research (4th edition). Upper Saddle River, NJ: Pearson Education, Inc.

De chazal, E. (2014). Effective listening is essential in an academic context. Retrivied from: https:// mww.britishcouncil.org/voices-magarine/prepare-english-language-students-academic-listening.

Educational Testing Service Team. (2012). Practice test for TOEFL Junior Standard ataest. New York, NY: Educational Testing Service.

Educational Testing Service Team. (2015). Handbook for the TOEFL Junior Standard Test. New York, NY: Educational Testing Service.

Erlina, D., Marzulina, L., Pitaloka, N.L., Astrid, A., Fikri Yansyah, F., \& Mukminin, A. (2018). Research on educational media: Balancing between local and target language cultures in English electronic textbooks. The Turkish Online Journal of Educational Technology, 17(2), 111119.

Fazeli, S. H. (2011) The relationship between the neuroticism trait and use of the English language learning strategies. International Journal of Linguistics, 3(1).

Fraenkel, J. R., Wallen, N. E., \& Hyun, H. H. (8th Eds.). (2012). How to evaluate research in education. New York, NY: McGraw-Hill.

Gilakjani, A., P., \& Ahmad, M., R. (2011). A study of factors affecting EFL learners' English listening comprehension and the strategies for improvement. Journal of Language Teaching and Research, 2(5), 977-988.

Goh, C. M. (2000). A cognitive perspective on language learners' listening comprehension problems. System, 28, 55-75. 
Golchi, M. M. (2012). Listening anxiety and its relationship with listening strategy use and listening comprehension among Iranian IELTS learners. International Journal of English Linguistics, 2(4), 115-128.

Habibi, A., Sofwan, M., \& Mukminin, A. (2016). English teaching implementation in Indonesian pesantrens: teachers'demotivation factors. Indonesian Journal of English Teaching, 5(2), 199213.

Habibi, A., Mukminin, A., Sofwan, M., \& Sulistiyo, U. (2017). Implementation of classroom management by English teachers at high schools in Jambi, Indonesia. Studies in English Language and Education, 4(2), 172-189.

Hamouda, A. (2013). An investigation of listening comprehension problems encountered by Saudi students in the efl listening classroom. International Journal of Academic Research in Progressive Education and Development 2(2), 2226-6348.

Haryanto, E., \& Mukminin, A. (2012). the global, the national and the local goals: English language policy implementation in an Indonesian international standard school. Excellence in Higher Education Journal, 3(2), 69-78.

Hismanoglu, M. (2000). Language learning strategies in foreign language learning and teaching. The Internet TESL Journal, 7(8). Retrivied from: http://iteslj.org/Articles/HismanogluStrategies.html

Hurd, S., \& Lewia, T. (2008). Language learning strategies in independent settings. Bristol, UK: Cromwell Press Ltd.

Jones, L. C. (2003). Supporting listening comprehension and vocabulary acquisition with multimedia annotations: The students' voice. CALICO Journal, 21(1), 41-65.

Lee, C. K. (2010). An overview of language learning strategies. Arecls, 7, 132-152.

Liubiniene, V. (2009). Developing listening skills in CLIL. KALBU STUDIJOS, 15.

Malkawi, A. H. (2010). Listening comprehension for tenth grade students in tabaria high school for girls. Journal of Language Teaching and Research, 1(6), 71-775.

Makmur, Ismiyati, Y., Mukminin, A., \& Verawaty. (2016). In search of good student teachers in writing skill: The impact of different task variance on EFL writing proficiency. International Journal of Academic Research in Education, 2 (1). http://dx.doi.org/10.17985/ijare.45901

Moghadam, M. B., Ghanizadeh, A., \& Pazhouhesh, M. (2016). Scrutinizing listening strategies among Iranian EFL University students. International Journal of Educational Investigations, 3(3), 11-22.

Mukminin, A., Ali, Rd. M., \& Fadloan, M.J. (2015). Voices from within: Student teachers' experiences in english academic writing socialization at one Indonesian teacher training program. The Qualitative Report, 20 (9), 1394-1407.

Mukminin, A., Noprival, Masbirorotni, Sutarno, Arif, N., \& Maimunah. (2015). EFL Speaking anxiety among senior high school students and policy recommendations. Journal of Education and Learning, 9(3), 217-225.

Mukminin, A., Muazza, Hustarna, \& Sari, S.R. (2015). Stories from the frontlines: In-service teachers' demotivating factors and policy recommendations. International Journal of Academic Research in Education, 1(2), 40-52. DOI: 10.17985/ijare.56085.

Naning, Z. A, \& Hayati, R. (2011). The correlation between learning style and listening achievement of English education study program students of Sriwijaya University. Jurnal Holistics, 3(5).

Norfleet, M. (2016). Factors that affect listening comprehension. Retrivied from: http:/ / education.seattlepi.com/ factors-affect-listening-comprehension $3720 . \mathrm{html}$

Ou-chun, O. (2011). Influence of English proficiency on postgraduate students' use of language learning strategies. Sino-US English Teaching, 8(12). 766-772. 


\section{Edukasi}

Oxford, R. L., \& Burry-Stock, J. A. (1995). Assessing the use of language learning strategies worldwide with the esl/efl version of the strategy inventory for language learning (sill). Elsevier Science Ltd, 23(1), 1-23.

Oxford, R. L. (1990). Language learning strategies: what every teacher should know. Boston: Heinle \& Heinle.

Oxford, R. L. (2003). Language learning styles and strategies: Concepts and relationships. IRAL, 41(2003), 271-278.

Saputra, H., \& Marzulina, L. (2015). Teaching Writing by Using Process Genre Approach to the Eighth Grade Students of SMP Negeri 22 Palembang. Edukasi: Jurnal Pendidikan Dan Pengajaran, 2(1), 1-12. http://jurnal.radenfatah.ac.id/index.php/edukasi/article/view/592

Pannak, O., \& Chiramanee, T. (2011). Language learning strategies used by first year students at Thaksin University, Songkhla Campus, Thailand. The 3rd International Conference on Humanities and Social Sciences, 1-12.

Richard, J. C. (2008). Teaching listening and speaking: From theory to practice. New York, NY: Cambridge University Press.

Suwanarak, K. (2012). English language learning belifes, learning strategies and achievement of masters students in Thailand. TESOL as a Global Trade Ethics, Equity and Ecology, 1-15.

Yousefenia, D. (2012). The effect of self-regulated strategy development instruction on the listening performance of Iranian EFL learners. (Unpublished Master's Thesis). Sheikhbahaee University, Isfahan, Iran. 